International Journal of Engineering \& Technology, 7 (4.20) (2018) 180-184
International Journal of Engineering \& Technology
SPC
Website: www.sciencepubco.com/index.php/IJET
Research paper

\title{
Influence of Micro- Size Silica Powder on Physical and Rheological Characteristics of Asphalt Binder
}

\author{
${ }^{1}$ Hussein H. Zghair* $\quad{ }^{1}$ Hasan H. Joni, ${ }^{1}$ Maan S. Hassan \\ ${ }^{1}$ Civil Engineering Department, University of Technology, 10066, Baghdad, Iraq. \\ *E-mail address:11539@uotechnology.edu.iq
}

\begin{abstract}
During the last years, the use of by-product materials, such as micro silica, $\mathrm{mS}$, especially in the area of highway pavement materials has received increasing interest. The experimental work of this research focused on the investigation of the potential use of micro silica powder to enhance the rheological properties of asphalt cement binder. To achieve this aim, mixtures with various contents of micro silica and asphalt were prepared. The asphalt cement and micro silica were first tested. The micro silica powder has been mixed with the asphalt cement at a temperature of $140{ }^{\circ} \mathrm{C}$ by conventional mechanical mixer at $2000 \mathrm{rpm}$. Two mixing time durations were implemented to produce the modified asphalt mixtures: 30 and 60 minutes. The $\mathrm{mS}$ modified asphalt was then evaluated for the empirical physical and rheological properties including penetration value, softening point temperature, temperature susceptibility, Brookfield Rotational viscosity and ductility. The experimental work results showed that micro silica powder reduces penetration value and increases softening point temperature. Progressive increases in $\mathrm{mS}$ content were found to increase Brookfield Rotational Viscosity (RV) and tend to decrease the ductility of the studied specimens. The negative effects of added $\mathrm{mS}$ were more pronounced at values more than $4 \%$. Finally, the increase in mixing time duration may slightly lead to good micro silica powder dispersion into the asphalt matrix, but it is the consumption of energy and cost.
\end{abstract}

Keyword: Asphalt binder properties, micro silica, modification process

\section{Introduction}

Asphalt cement is a complex chemical composition, often it shows both viscous and elastic behaviors which largely based on temperature and loading time $[\mathbf{1 , 2}$. Asphalt cement is generally known as common binder material used to the construction of flexible pavements, because of its unique viscoelastic characteristics $[3,4]$. However, higher traffic loads globally together with the variation of weather conditions leads to quick deterioration of highway pavement materials. To control these effects, pavement of highway request binder material with higher performance than normal grade asphalt cement. Consequently, nowadays the construction of flexible pavements needs for modified asphalt cement [5].

In the process of asphalt cement modification, different materials have been used for modifying the base asphalt cement and to improve the mechanical performance of asphalt binder material and mixtures. These materials include the styrene-butadiene-styrene (SBS) [6-9], lime [10, 11], crumb rubber [12] and electronic waste powders [13-14].

Micro Silica is ultra-fine non-crystalline silica which produced in electrical arc ovens as a waste material from the production of silicon elements. The silica fume has the high content of noncrystalline silicon oxides. The shape of micro silica is round particles, diameter typically closed to 0.1 to $0.2 \mu \mathrm{m}$ [15-17].

Micro silica was added to the control asphalt binder PG 64-22 at different contents to increase viscosity values and reduce the oxidation rate of asphalt binder can be obtained by addition of micro silica to the control asphalt binder [18].

The object of this research is to investigate the impact of micro silica particles on the empirical physical and rheological properties of asphalt cement binder including penetration value, softening point temperature, temperature sensitivity (penetration index), Brookfield rotational viscosity and ductility value by three various percentages $(2 \%, 4 \%$ and $6 \%)$ of micro silica powder. As well, studying the impact of mixing time duration on the distribution of micro silica powder in asphalt cement binder, it was also conducted to evaluate the $\mathrm{mS}$ modified asphalt binder properties.

\section{Research methodology and experimental program}

\subsection{Material used}

\subsubsection{Asphalt cement}

This research has used asphalt cement 60/70 penetration type Brought from the Dora refinery at the middle region of Iraq. Table 1 shows rheological properties of asphalt cement binder.

\subsubsection{Micro silica powder}

Micro silica is a non-crystalline of silicon oxide. Chemical analysis of micro silica used is tabulated in Table 2, whereas the physical features are shown in Table 3. Results showed the micro silica powder conforms to requirements of ASTM C 1240 [15]. 
Table 1: Physical characteristics of asphalt cement used in this work

\begin{tabular}{|c|c|c|c|c|c|}
\hline Test & $\begin{array}{c}\text { Test } \\
\text { Conditions }\end{array}$ & Standard & Results & \multicolumn{2}{|c|}{$\begin{array}{l}\text { Standard Limits of } \\
\text { Iraqi Specification } \\
\text { (SCRB/ R9. } \\
2003)[24 \mid\end{array}$} \\
\hline Penetration & $(0 . \operatorname{lmm})$ & $\begin{array}{l}\text { ASTM } \\
\text { D5[19] }\end{array}$ & 66 & \multicolumn{2}{|c|}{$60-70$} \\
\hline Ductilify & $\mathrm{cm}$ & $\begin{array}{c}\text { ASTM } \\
\text { D113 }[20]\end{array}$ & 130 & \multicolumn{2}{|c|}{$>100$} \\
\hline $\begin{array}{l}\text { Flash point } \\
\text { Fire point }\end{array}$ & $+\ldots$. & $\begin{array}{l}\text { ASTM D } 92 \\
{[21]}\end{array}$ & $\begin{array}{l}\text { Flash } \\
302^{\circ} \mathrm{C}\end{array}$ & \multicolumn{2}{|c|}{$>232^{\circ} \mathrm{C}$} \\
\hline & & & $\begin{array}{l}\text { Fire } \\
310^{\circ} \mathrm{C}\end{array}$ & \multicolumn{2}{|c|}{$\ldots$} \\
\hline $\begin{array}{l}\text { Thin - film } \\
\text { oven test }\end{array}$ & $\begin{array}{c}163^{\circ} \mathrm{C} \\
50 \mathrm{gm}, 5 \mathrm{hr} .\end{array}$ & $\begin{array}{c}0.222<1 \\
\text { Mass loss }\end{array}$ & $\begin{array}{l}\text { Pen: } \\
89.9\end{array}$ & \multicolumn{2}{|c|}{$>52$} \\
\hline & & & $\begin{array}{l}\text { Duc. } \\
120\end{array}$ & \multicolumn{2}{|c|}{$>50$} \\
\hline $\begin{array}{l}\text { Rotational } \\
\text { Viscosity }\end{array}$ & Pa. sec & $\begin{array}{c}\text { ASTM } \\
\text { D4402 [22] }\end{array}$ & \multicolumn{2}{|c|}{$\begin{array}{l}\text { (a) } 135^{\circ} \mathrm{C}-430 \\
\text { (a) } 165^{\circ} \mathrm{C} 128\end{array}$} & $\cdots$ \\
\hline $\begin{array}{l}\text { Softening } \\
\text { point }\end{array}$ & $\ldots .$. & $\begin{array}{l}\text { ASTM D } 36 \\
{[23]}\end{array}$ & 49.5 & \multicolumn{2}{|r|}{$\ldots$} \\
\hline $\begin{array}{l}\text { Penetration } \\
\text { index }\end{array}$ & ..t. & $\begin{array}{l}\text { ASTM D 36 } \\
{[23]}\end{array}$ & -0.665 & \multicolumn{2}{|r|}{$\ldots$} \\
\hline
\end{tabular}

Table 2: Chemical Analysis of Micro Silica Compostions*

\begin{tabular}{|l|l|l|}
\hline Oxide Composition & Oxide content \% & ASTM C1240-15 \\
\hline $\mathrm{SiO} 2$ & 91.51 & Min. 85\% \\
\hline $\mathrm{Fe} 2 \mathrm{O} 3$ & 0.44 & $<2.5 \%$ \\
\hline $\mathrm{Al}_{2} \mathrm{O}_{3}$ & 0.71 & $<1 \%$ \\
\hline $\mathrm{SO}_{3}$ & 0.95 & $<1 \%$ \\
\hline $\mathrm{K}_{2} \mathrm{O}+\mathrm{Na}_{2} \mathrm{O}$ & 1.38 & $<3 \%$ \\
\hline $\mathrm{CaO}$ & 0.90 & $<1 \%$ \\
\hline L.O. I & 4.39 & Max. 6\% \\
\hline
\end{tabular}

Table 3: Physical Characteristics of Micro Silica Particles *

\begin{tabular}{|l|l|l|}
\hline Property & Result & ASTM C1240-15 \\
\hline Size & 0.15 & $\sim 0.15 \mu \mathrm{m}$ \\
\hline Color & Grey & - \\
\hline Specific surface area, & 17000 & $\geq 15000 \mathrm{~cm}^{2} / \mathrm{g}$ \\
\hline Specific gravity, $\mathrm{kg} / \mathrm{m}^{3}$ & 2.2 & - \\
\hline Physical form & Powder & - \\
\hline Bulk Density & 0.6 & $0.5 \pm 0.1 \mathrm{~kg} / \mathrm{liter}$ \\
\hline Moisture & $0 \%$ & $<2 \%$ \\
\hline
\end{tabular}

* Chemical and physical analysis were conducted according to manufacture and National Center for Construction Laboratories and Researches.

\subsection{Modification process}

Micro silica $(\mathrm{mS})$ modified asphalt specimens were prepared by heating the asphalt cement at $140{ }^{\circ} \mathrm{C}$, based on the viscosity of base asphalt binder. At $140{ }^{\circ} \mathrm{C}$ asphalt cement sufficiently turns into a liquid. Then, micro silica powder a weighted $2 \%, 4 \%$ and 6 $\%$ ( low, medium and high percent) gradually added to asphalt cement weight. The $\mathrm{mS}$ modified asphalt binder was mixed using a desktop conventional mechanical mixer at the rate of $2000 \mathrm{rpm}$ to obtain a homogeneous composite material and reduce the agglomeration, for different mixing time ranged ( from 30 to 60) minutes as shown in the plate 1 .

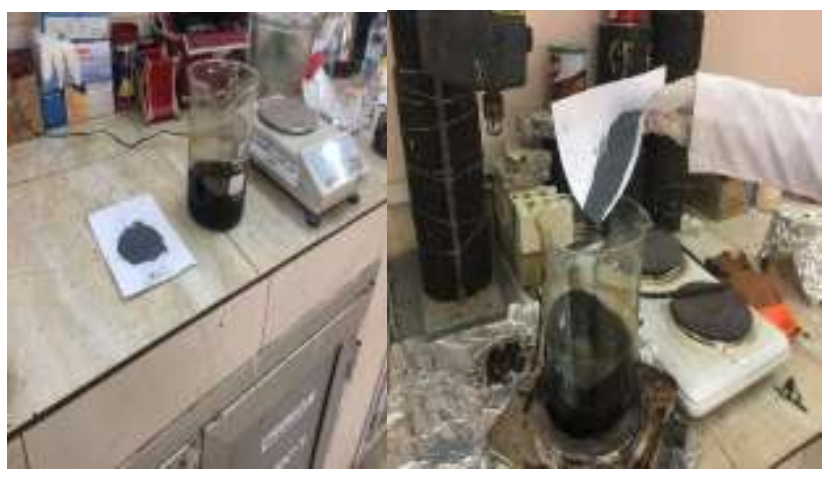

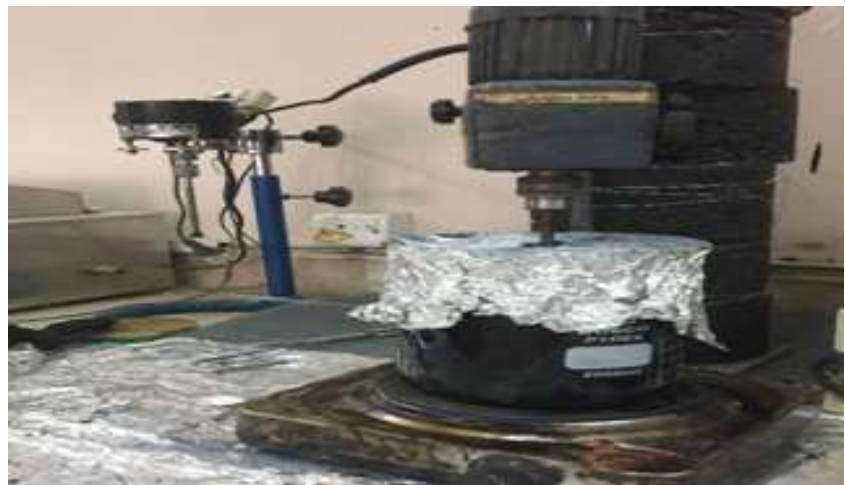

Plate 1: Process of mixing of micro silica with asphalt cement under control temperature by using the electronic oven.

\subsection{Experimental Tests}

This study was focused on the determination the optimum content of micro silica powder by physical and rheological properties (penetration value, softening point temperature, temperature sensitivity (PI), ductility value and rotational viscosity) for original and $\mathrm{mS}$ modified asphalt. Tests were achieved according to the standard specifications such as ASTM-D5, ASTM-D36, ASTM D4402 and ASTM-D113 respectively.

\section{Results and discussion}

The most important tests that are used to determine the physical and rheological characteristics of asphalt binder are the penetration value and the softening point temperature, they are conducted to original and $\mathrm{mS}$ modified asphalt binder. Figures $1 \& 3$, present the results of penetration value and softening point temperature for original and $\mathrm{mS}$ modified asphalt binder. From these figures, it can be seen that the penetration value of $\mathrm{mS}$ modified asphalt binder is decreased with increasing of softening point to adding the micro silica particles. Attributed to increase the hardness at moderate temperatures by diffusion and adsorption of micro silica powder in asphalt cement leads to absorption of oily material in the maltene phase and transform to the resin in the asphaltene phase of asphalt cement. Also, the micro silica particles are stiff and more than asphalt binder's stiffness [25]. Micro silica powder had a significant effect on the rheological characteristics of asphalt binder based on the obtained results. As can be seen in Figures $2 \& 4$, increasing of mixing time duration of modified asphalt improves the rheological properties of asphalt cement until 60 minutes, but elongated mixing time may slightly lead to a good distribution of micro silica and it is more energy consumption and less economical cost.

The asphalt binder behavior to different temperature can be predicted in the application of pavement based on penetration index and it is a quantitative measure [26]. PI values were calculated from the relationship between penetrations value and softening point temperatures. Figure(5), presented PI values versus micro silica content, as seen that the PI values of $\mathrm{mS}$ modified asphalt binder decrease with increasing of the micro silica content. This indicates that the micro silica powder has been adversely affecting on temperature susceptibility of the $\mathrm{mS}$ modified asphalt binder. But all values of PI were within the range of the standard specifications $(-2$ to +2$)$ and can be used to the construction of pavements [26].

Figure 6 , shows ductility value of $\mathrm{mS}$ modified asphalt binder was reduced by increasing micro silica powder content, due to reduce the oily materials (absorption of the light volatiles) in maltene phase and lead to increase the stiffness of $\mathrm{mS}$ modified asphalt binder. Also, the longer mixing time leads to decrease ductility of $\mathrm{mS}$ modified asphalt as shown in Figure 7, the result is attributed to decrease the homogeneity and increases the stiffness of $\mathrm{mS}$ modified asphalt resulting from micro-silica modification [27]. 
The desired workability of asphalt binder at high temperatures (during mixing and compaction) are determined by Brookfield rotational viscosity test. Figures 8 to11, presented the viscosity values for the original and $\mathrm{mS}$-modified asphalt binder at a temperature range of $135-165^{\circ} \mathrm{C}$. From these figures, it can be seen that the added $\mathrm{mS}$ content increases the viscosity of asphalt binder. Attributed to increase surface area and reactivity by diffusion and adsorption of micro silica powder in asphalt binder [28]. The high viscosity of asphalt binder is suitable for paving and maintenance of road pavement which bearing heavy traffic load. Superpave specification obligates that used asphalt binder viscosity must not be more than $3000 \mathrm{mPa}$ s. However, all the modified binders conform to this requirement.

\section{Mixing Time (30 min.)}

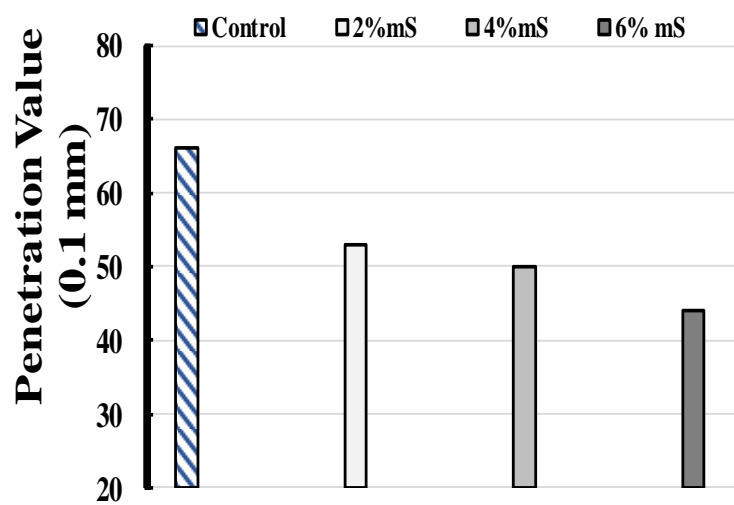

Fig. 1: Penetration Value of Original Asphalt and mS-Modified asphalt at Mixing Time 30 Minute.

Mixing Time (60 min.)

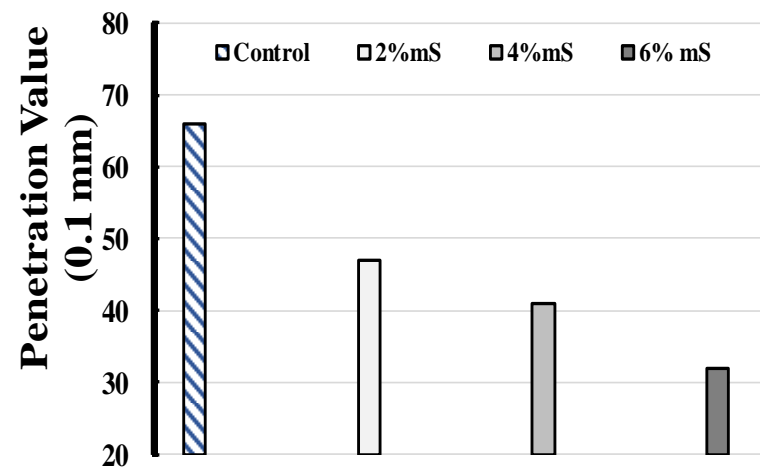

Fig. 2: Penetration Value of Original Asphalt and mS-Modified asphalt at Mixing Time 60 Minute.

\section{Mixing Time (30 min.)}

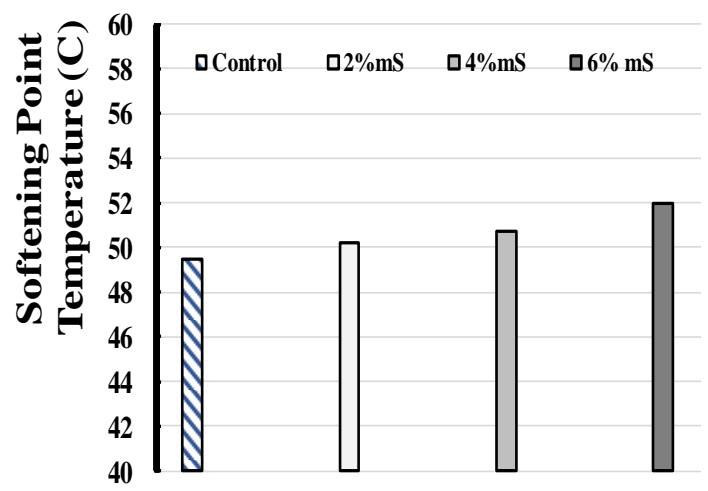

Fig.3: Softening Point of Original Asphalt and mS-Modified asphalt at Mixing Time 30 Minute.
Mixing Time (60 min.)

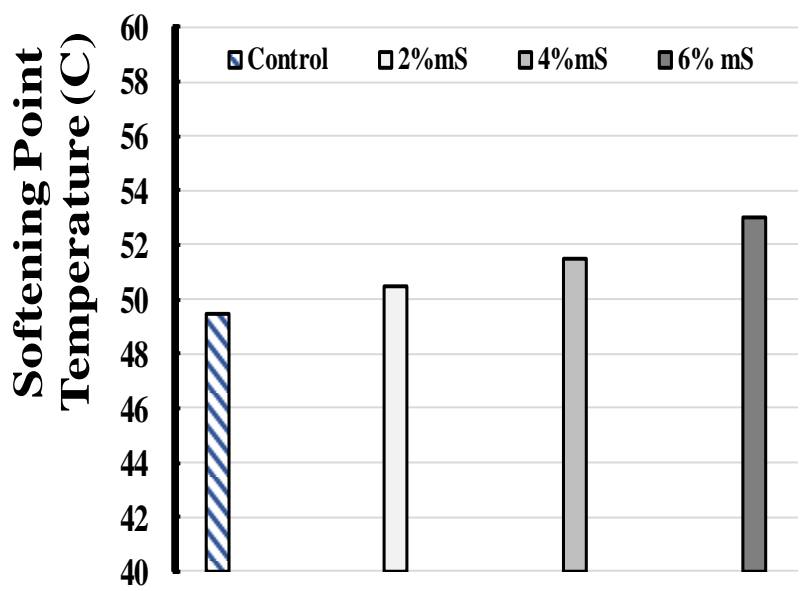

Fig.4: Softening Point of Original Asphalt and mS-Modified asphalt at Mixing Time 60 Minute.

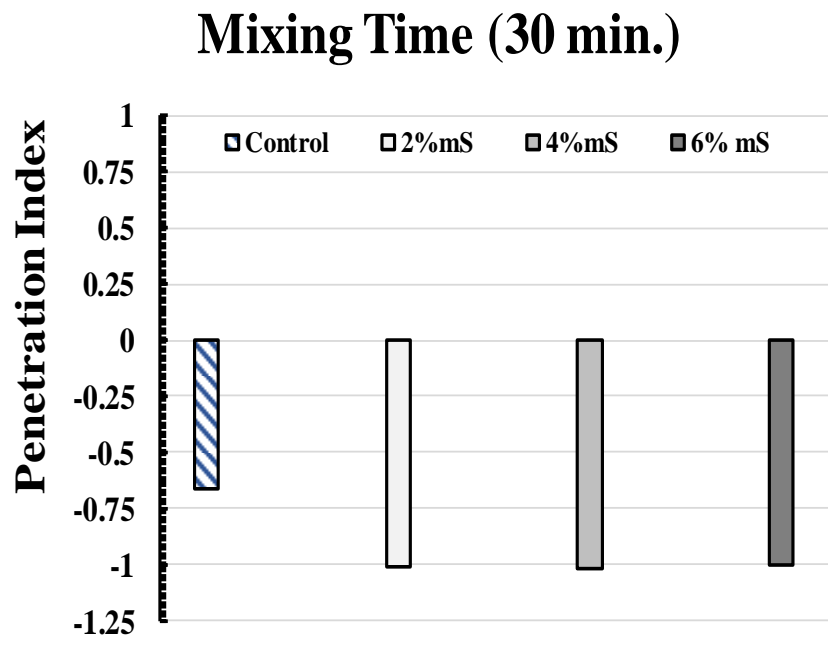

Mixing Time (60 min.)

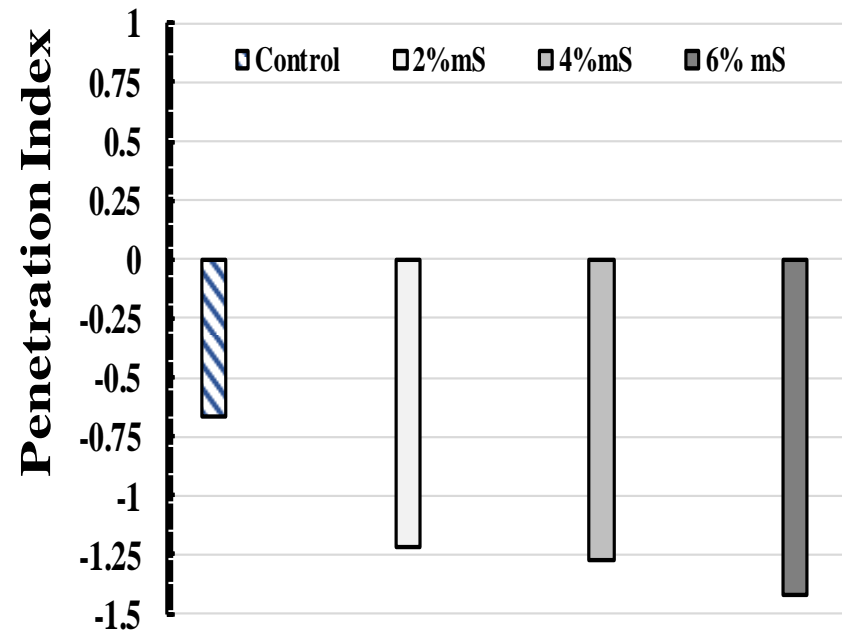

Fig.5: Penetration Index of Original Asphalt and mS-Modified asphalt at Mixing Time $30 \& 60$ minutes. 


\section{Mixing Time (30 min.)}

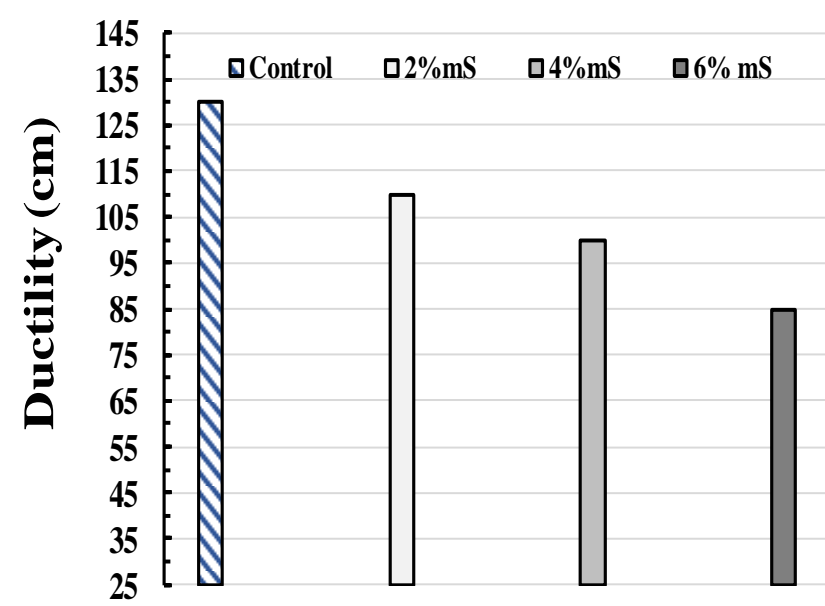

Fig.6: Ductility of Original Asphalt and mS-Modified asphalt at Mixing Time 30 minute.

Mixing Time (60 min.)

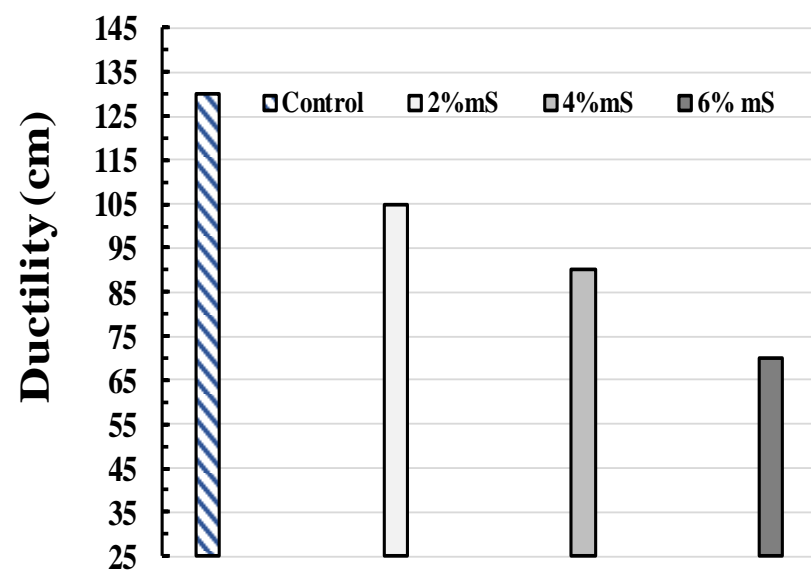

Fig.7: Ductility of Original Asphalt and mS-Modified asphalt at Mixing Time 60 minute.

Mixing Time (30 min.)

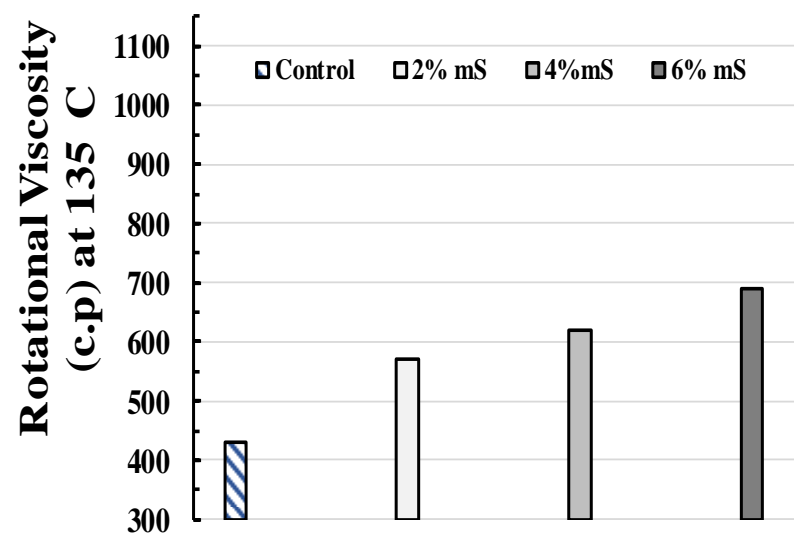

Fig.8: A viscosity of Original Asphalt and mS-Modified asphalt at Mixing Time 30 minute.

\section{Mixing Time (60 min.)}

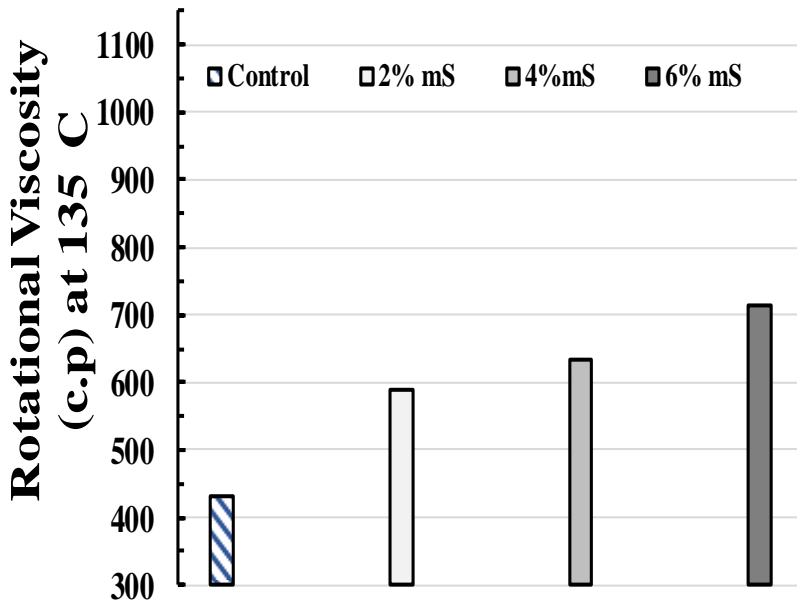

Fig.9: A viscosity of Original Asphalt and mS-Modified asphalt at Mixing Time 60 minute.

Mixing Time (30 min.)

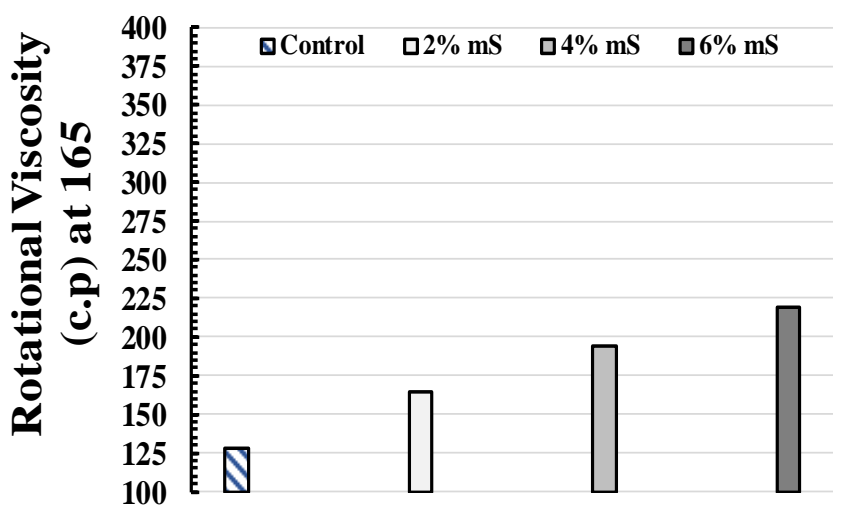

Fig.10: A viscosity of Original Asphalt and mS-Modified asphalt at Mixing Time 30 minute.

\section{Mixing Time (60 min.)}

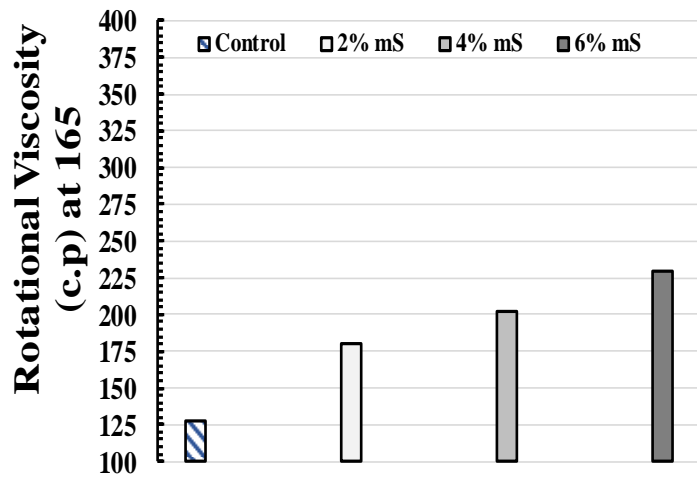

Fig.11: A viscosity of Original Asphalt and mS-Modified asphalt at Mixing Time 60 minute.

\section{Conclusions}

The main object of this work was to describe the physical and rheological properties of $\mathrm{mS}$ modified asphalt cement. Using modifier as micro silica powder had the positive effect on the physical and rheological characteristics of asphalt cement. Based on experimental work results were conducted on the asphalt cement with various micro silica percentages, the results were analyzed and 
compared with standard specification. The following point can be concluded:

1. mS modified asphalt increased the softening point temperature, whilst penetration value decreased by increasing the micro silica content, due to a stiffness of the micro silica particles are stiffer than the asphalt binder.

2. Viscosity values of $\mathrm{mS}$ modified asphalt binder increase with the added micro silica content and all viscosity values were within the standard specifications.

3. Temperature susceptibility (PI) of $\mathrm{mS}$ modified asphalt binder was reduced by increasing the content of micro silica, indicating that the micro silica has adversely effect on the temperature susceptibility of the $\mathrm{mS}$ modified asphalt binder. But all values of PI were within the range of the specifications $(-2$ to +2$)$ and can be used in the pavements construction.

4. When using the conventional mechanical mixer at 2000 $\mathrm{rpm}$ for mixing time about (60) minutes may slightly lead to a good distribution of micro silica powder in the asphalt matrix, but it is energy-consuming and economically inefficient.

5. A 6\% micro silica by asphalt weight enhanced the rheological properties of the $\mathrm{mS}$ modified asphalt cement. The mS modified asphalt cement became more proper for construction of pavements in hot weather conditions. This indicates that the lower penetration value, the higher softening point temperature, and viscosity.

6. The adverse effects of added $\mathrm{mS}$ were more pronounce at values more than $4 \%$ on the asphalt binder characteristics such as ductility, attribution to decrease the homogeneity and increase the stiffness of the $\mathrm{mS}$ modified asphalt cement.

\section{References}

[1] S. Peters, T. Rushing, E. Landis, and T. Cummins, 2010, "Nano cellulose and micro cellulose fibers for concrete," Transportation Research Record: Journal of the Transportation Research Board, pp. 25-28.

[2] Y. Yildirim, 2007, "Polymer modified asphalt binders", Construction and Building Materials, vol. 21, pp. 66- 72.

[3] L. Loeber, G. Muller, J. Morel, and O. Sutton, 1998, "Bitumen in colloid science: a chemical, structural and rheological approach," Fuel, vol. 77, pp. 1443-1450.

[4] S.-p. Wu, L. Pang, L.-t. Mo, Y.-c. Chen, and G.-j. Zhu, 2009, "Influence of ageing on the evolution of structure, morphology and rheology of base and SBS modified bitumen," Construction and Building Materials, vol. 23, pp. 1005-1010.

[5] J. Lamontagne, P. Dumas, V. Mouillet, and J. Kister, 2001, "Comparison by Fourier transform infrared (FTIR) spectroscopy of different ageing techniques: application to road bitumen's," Fuel, vol. 80, pp. 483-488.

[6] C. Ouyang, S. Wang, Y. Zhang and Y. Zhang, 2006, "Improving the ageing resistance of styrene-butadiene-styrene tri-block copolymer modified asphalt by addition of antioxidants," Polymer Degradation and Stability, vol. 91, no. 4, pp. 795-804.

[7] B. V. Kok and M. Yilmaz, 2009, "The effects of using lime and styrene butadiene- styrene on moisture sensitivity resistance of hot mix asphalt," Construction and Building Materials, vol. 23, no. 5, pp. 1999-2006.

[8] M. J. Khattak, G. Y. Baladi, and L. T. Drzal, 2007, "Lowtemperature binder-aggregate adhesion and mechanistic characteristics of polymer modified asphalt mixtures," Journal of Materials in Civil Engineering, vol. 19, no. 5, pp. 411-422.

[9] Hasan H. Joni , Ethar K. Shaker, 2017," Determination of the acceptable range of mixing and compaction temperatures for modified asphalt mixture with styrene butadine styrene (SBS)", International Journal of Current Engineering and Technology.

[10] S.-C. Huang, R. E. Robertson, J. F. Branthaver, and J.C. Petersen 2005, "Impact of lime modification of asphalt and freeze-thaw cycling on the asphalt-aggregate interaction and moisture resistance to moisture damage," Journal of Materials in Civil Engineering, vol. 17 , no. 6, pp. 711-718.

[11] D. Lesueur, J. Petit, and H.-J. Ritter, 2013, "The mechanisms of hydrated lime modification of asphalt mixtures: a state-of-the-art review," Road Materials and Pavement Design, vol. 14, no. 1, pp. $1-16$.

[12] D. Lo Presti, 2013, "Recycled Tire Rubber Modified Bitumen's for road asphalt mixtures: a literature review," Construction and Building Materials, vol. 49, pp. 863-881.

[13] B. W. Colbert and Z. You, 2012, "Properties of modified asphalt binders blended with electronic waste powders" ,Journal of Materials in Civil Engineering, vol. 24, no. 10, pp. 1261-1267.

[14] Hasan H. Joni and Hussein H. Zghair, 2016, "Effect of Adding Used-Foundry Sand on Hot Asphalt Mixtures Performance", Eng. \&Tech .Journal, Vol.34, Part (A), No.6.

[15] ASTM C1240, 2015," Standard Specification for Silica Fume Used in Cementitious Mixtures".

[16] MS Hassan, IN Gorgis and AA Jaber, 2017," Fresh and hardened properties of Nano silica and micro silica contained selfconsolidating concretes", ARPN 12 (17), 5140-5153.

[17] A Jaber, I Gorgis and M Hassan ,2017" Relationship between splitting tensile and compressive strengths for self-compacting concrete containing nano-and micro silica", MATEC Web of Conferences $162,02013$.

[18] Nader Abutalib, Elham H. Fini, Sassan Aflaki and Taher M. AbuLebdeh , 2015," Investigating Effects of Application of Silica Fume to Reduce Asphalt Oxidative Aging", American Journal of Engineering and Applied Sciences.

[19] ASTM D5, 2015," Standard Test Method for Penetration of Bituminous Materials", Annual Book of Standards American Society for Testing and materials, Vol.04.03.

[20] ASTM-D113, 2015," Standard Test Method for Ductility of Bituminous Materials ", Annual Book of Standards American Society for Testing and materials, Vol.04.03.

[21] ASTM D92, 2015," Standard Test Method for Flash and Fire Points by Cleveland Open Cup Tester", Annual Book of Standards American Society for Testing and materials, Vol.04.03.

[22] ASTM D4402, 2015," Standard Test Method for Viscosity Determination of Asphalt at Elevated Temperatures Using a Rotationa Viscometer", Annual Book of Standards American Society for Testing and materials Vol.04.03.

[23] ASTM D36, 2015, "Standard Test Method for Softening Point of Bitumen (Ring-and-Ball Apparatus)", Annual Book of Standards American Society for Testing and materials, Vol.04.04.

[24] State Organization for Roads and Bridges, 2003, "Hot Asphaltic Concrete Pavement, Iraqi Standard Specification", Ministry of Housing and Construction, Department of Design and Study, Section R9.

[25] Taherkhani, H.1* and Afroozi, S., 2016," The properties of nano silica-modified asphalt cement", Petroleum Science and Technology, 1381-1386

[26] D. Whiteoak, 2015, The Shell Bitumen Handbook, fifth edition.

[27] Taherkhani, H.1* and Afroozi, S.2, 2017," Investigating the Performance Characteristics of Asphaltic Concrete Containing NanoSilica", Civil Engineering Infrastructures Journal, 50(1): 75 - 93.

[28] Enieb Mahmoud, Diab Aboelkasim, 2017," Characteristics of Asphalt Binder and Mixture Containing Nanosilica", International Journal of Pavement Research and Technology 10,148-157. 